\title{
Antioxidant Effect of Leaf, Stem, and Root Extracts of Zingiber officinale as Cosmetic Materials
}

\author{
Sang Moo Lee, Chun Dug Kim * \\ Department of Cosmetology Science, Nambu University, Gwangju, Korea
}

\author{
*Corresponding author: Chun Dug Kim, \\ Department of Cosmetology Science, \\ Nambu University, 23 advanced Jungang- \\ ro, Gwangsan-gu, Gwangju 62271, Korea \\ Tel.: +82 629700139 \\ Fax: +82 629726200 \\ Email: chun@nambu.ac.kr
}

\section{Received November 25, 2020 \\ Revised March 9, 2021 \\ Accepted March 9, 2021 \\ Published March 30, 2021}

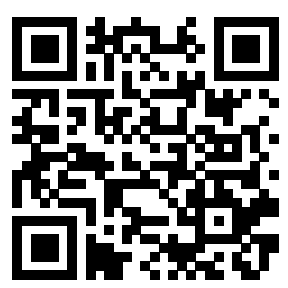

\begin{abstract}
Purpose: In this study, we used Zingiber officinale ( $Z$. officinale) leaf, stem, and root extracts to evaluate their potential as cosmetic materials. Methods: We measured DPPH radical-scavenging activity, total polyphenolic and flavonoid contents, ABTS radical scavenging activity, and SOD-like physiological activity to confirm the antioxidant effect to assess the potential of $Z$. officinale leaf, stem, and root extracts as cosmetic materials. Furthermore, the protective effect on oxidative stress caused by $\mathrm{H}_{2} \mathrm{O}_{2}$ in $\mathrm{HaCaT}$ cells and proliferative effect in dermal papilla cells were assessed. Results: As a result of the antioxidant effect of $Z$. officinale leaf, stem, and root extracts, DPPH radical-scavenging activity was measured at a concentration of 400 $\mu \mathrm{g} / \mathrm{mL}$, and it was $88.78 \%$ in $Z$. officinale leaf extract, $70.12 \%$ in stem extract, and $65.52 \%$ in root extract. Total polyphenolic content was $170.22 \mu \mathrm{g} / \mathrm{mL}$ (leaf), 120.27 $\mu \mathrm{g} / \mathrm{mL}$ (stem), and $146 \mu \mathrm{g} / \mathrm{mL}$ (root), whereas total flavonoid content was $98.52 \mu \mathrm{g} /$ $\mathrm{mL}$ (leaf), $70.26 \mu \mathrm{g} / \mathrm{mL}$ (stem), and $46.12 \mu \mathrm{g} / \mathrm{mL}$ (root). ABTS radical scavenging activity was measured at a concentration of $400 \mu \mathrm{g} / \mathrm{mL}$, and it was $88.26 \%$ (leaf), $70.73 \%$ (stem), and $64.13 \%$ (root). Further, SOD-like physiological activity was $65.22 \%$ (leaf), $57.53 \%$ (stem), and $50.21 \%$ (root). The protective effect on oxidative stress caused by $\mathrm{H}_{2} \mathrm{O}_{2}$ in $\mathrm{HaCaT}$ cells was $82.18 \%$ (leaf), $78.98 \%$ (stem), and $70.27 \%$ (root) at a concentration of $100 \mu \mathrm{g} / \mathrm{mL}$. Our results confirmed that $Z$. officinale leaf extract has high protective effects on cell damage caused by $\mathrm{H}_{2} \mathrm{O}_{2}$, showing a $32 \%$ increase. Moreover, the proliferative effect in dermal papilla cells was $158.63 \%$ (leaf), $140.41 \%$ (stem), and $132.40 \%$ (root) when cells were cultured for $72 \mathrm{~h}$ at a concentration of $100 \mu \mathrm{g} / \mathrm{mL}$. Conclusion: Thus, $Z$. officinale leaf extract has the highest antioxidant effect, HaCaT cell protective effect, and proliferative effect in dermal papilla cells, indicating a possibility to be developed as a cosmetic material.
\end{abstract}

Keywords: Zingiber officinale, Antioxidant effect, $\mathrm{H}_{2} \mathrm{O}_{2}$, Dermal papilla cells, Cosmetic

\section{Introduction}

화장품 산업은 소비자 욕구의 다양화, 여성 경제활동 인구의 증 가, 소비 계층의 확대, 고령화 시대 진입 등으로 인해 지속적으로 새 로운 시장 창출이 예상되며 경제발전과 연계된 지속적 성장산업이다 (Ku \& Lee, 2018). 천연물 소재는 뷰티산업의 발전에 따른 화장품 원 료 개발에 있어서 매우 중요한 부분으로, 그 종류에 따라서 다양한 생 리활성을 나타낸다(Jang et al., 2015a), 식물유래 천연 성분에 대한 인식이 높아짐에 따라 생리활성물질을 다량으로 함유하고 있고, 인체
에 부작용이 적은 천연물에 대한 연구가 활발해지고 있으며(Kim \& Park, 2017; Kim \& Jang, 2016; Lee et al., 2018; Shim, 2018 ; Lee \& Ryu, 2019).

특히 부작용 낮은 천연물을 이용한 의약품 및 화장품에 대한 연 구가 웰빙 열풍과 함께 산업적 선호도가 증가하는 추세이다(Jang et al., 2015b). 기능성화장품의 개발에는 생리활성을 가지는 원료물질 의 개발이 선결과제이며, 검토해야 할 기능성은 항산화, 항염증, 항균 효과, 미백, 주름개선, 항노화 등이 있다(Cho, 2011).

피부는 인체의 최외각 층에 존재한 기관으로 다양한 환경적 요인과 
항상 접촉하고 있기 때문에 산화적 스트레스에 직접적으로 노출되어 있다(Chon et al., 2012a). 피부에서 활성산소는 세포막을 공격하여 이를 산화시키게 되고 산화된 지질에 의해 세포막이 손상되어 정상적 인 피부세포의 기능을 손실시키게 된다. 또한 피부의 효소적, 비효소 적 항산화 방어체계의 균형을 깨트리게 되어 피부가 지속적인 산화상 태에서 회복되지 못하게 되면서 피부는 거칠고 윤기가 없어지게 되며 이러한 과정의 반복은 피부노화가 진행될 수 있다(Park et al., 2018).

활성산소는 세포구성 성분들인 지질, 단백질, DNA 등에 대하여 비 선택적, 비가역적인 파괴 작용을 함으로써 각종 질병은 물론, 노화, 피 부질환을 일으키는 원인이 된다. 또한 지질과산화 반응 결과 생성되는 지질 과산화물도 세포에 대한 산화적 파괴로 인한 노화의 원인이 되기 도 한다. 따라서 활성산소 및 프리라디칼 소거활성을 갖는 항산화 소 재는 매우 유용한 화장품소재로 활용되고 있다(Yoo et al., 2005).

피부 표면의 대부분을 구성하고 있는 각질세포는 생체 대사과정에 서 필연적으로 발생하는 활성산소(reactive oxygen species, ROS)의 산화적 스트레스(oxidative stress) 초래로 궁극적으로 피부의 면역기 능 억제, 염증 유발, 탄력감소, 주름 및 기미, 주근깨 등의 질환들을 유 발하여 결국 피부 노화가 가속된다(Kim \& Bang, 2018).

생강(Zingiber offcinale Roscoe)은 열대 아시아가 원산지인 생강과 에 속하는 다년생 초본 식물의 하나로써, 그의 근경을 칭하기도 한다. 생강은 특유의 맛과 향기를 지니고 있어 기호성이 좋은 향신료의 하나 로써 날 생강, 건 생강, 정유(absolute, oleoresin) 등이 생강 제품을 위 한 소재로 유통되고 있다(Lee et al., 2011).

국내에서는 생강의 지상부인 줄기와 잎은 주로 뿌리를 목적으로 재 배되는 과정에서 유용하게 활용되지 못하고 거의 폐기되는 실정이다. 생강 뿌리는 각종 식품 첨가물 및 화장품 소재로 다양하게 이용되고 있지만 생강 잎이나 줄기에 대한 연구는 미비한 실정이다(Lee et al., 2014).

따라서 본 연구에서는 생강 잎, 줄기, 뿌리 추출물의 화장품 소재 로 가능성을 알아보기 위하여 $70 \%$ 주정 에탄올에 24 시간 추출하였다. 항산화효과는 DPPH 라디컬 소거능, 총 폴리페놀과 플라보노이드 함 량 측정, $\mathrm{ABTS}$ 라디컬 소거능, $\mathrm{SOD}$ 유사활성을 측정하였다. 그리고 $\mathrm{HaCaT}$ 세포 보호효과는 과산화수소로 유도된 산화적 손상에 대한 보 호효과를 MTT assay 방법으로 측정하였으며, 모유두 세포 증식효과 는 72시간을 배양하여 MTT assay 방법으로 측정하였다.

\section{Methods}

\section{1. 시료 추출}

시료 추출은 생강 전체를 잎, 줄기, 뿌리로 분리하여 각각 $100 \mathrm{~g}$ 에 $70 \%$ 주정 에탄올 $1 \mathrm{~L}$ 를 가하여 $60^{\circ} \mathrm{C}$ 에서 $24 \mathrm{~h}$ 추출하고, 추출액을 여 과(Whatman filter paper No.1; Whatman, UK)한 후에 회전식 감압 농축기(EYELA N-1000; Tokyo Rikakikai Co., Japan)로 농축한 후,
동결건조기(PVTFA 10AT; ILSIN, Korea)에 $72 \mathrm{~h}$ 동안 동결 건조하여 분말로 만들어 실험을 진행하였다.

\section{DPPH 라디컬 소거능}

DPPH radical을 이용한 항산화 활성은 Blois (1958) 방법을 변형하 여 사용하였다. $1 \mathrm{mM} \mathrm{DPPH}$ 용액 $100 \mu \mathrm{L}$ 와 생강 잎, 줄기, 뿌리 추

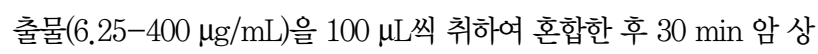
태에서 방치한 후 잔존 radical 농도를 Microplate Reader (Molecular Devices, USA) 를 이용하여 $517 \mathrm{~nm}$ 에서 측정하였다. 활성비교를 위하여 항산화 물질로 잘 알려진 butylated hydoxytoluene (BHT), ascorbic acid (vitamin C)와 비교하였다. DPPH 라디컬 소거능(\%)은 (1-시료의 흡광도/대조군의 흡광도 $) \times 100$ 에 의하여 산출하였다.

\section{3. 총 폴리페놀 함량}

총 폴리페놀 함량은 Folin \& Denis (1915) 방법에 따라, 생강 잎, 줄기, 뿌리 추출물 $(1 \mathrm{mg} / \mathrm{mL}) 50 \mu \mathrm{L}$ 에 증류수 $650 \mu \mathrm{L}$ 넣고 FolinDenis' reagent $50 \mu \mathrm{L}$ 를 가하여 $3 \mathrm{~min}$ 동안 실온에서 반응시킨다. 반 응시킨 후 $10 \%$ sodium carbonate $\left(\mathrm{Na}_{2} \mathrm{CO}_{3}\right.$; Sigma-Aldrich, USA) 포화용액을 $100 \mu \mathrm{L}$ 첨가하고, 최종 볼륨을 $1 \mathrm{~mL}$ 맞추기 위해 증류 수 $150 \mu \mathrm{L}$ 넣어 잘 혼합시켰다. $37^{\circ} \mathrm{C}$ water bath에 $1 \mathrm{~h}$ 반응시킨 후 Microplate Reader (iMARK ${ }^{\mathrm{TM}}$; BIO-RAD, USA)를 이용하여 725 $\mathrm{nm}$ 에서 흡광도를 측정하였다. 표준곡선은 tannic acid 농도 0-500 $\mu \mathrm{g} / \mathrm{mL}$ 이 되도록 하고 이로부터 총 폴리페놀 함량을 구하였다.

\section{4. 총 플라보노이드 함량}

총 플라보노이드 함량은 생강 잎, 줄기, 뿌리 추출물 $(1 \mathrm{mg} / \mathrm{mL})$ $100 \mu \mathrm{L}$ 에 $1 \mathrm{~mL}$ diethylene glycol을 첨가하고, 다시 $1 \mathrm{~N}$ sodium hydroxide (NaOH; Sigma-Aldrich) $100 \mu \mathrm{L}$ 넣어 잘 혼합시켜 $37^{\circ} \mathrm{C}$ water bath에 $1 \mathrm{~h}$ 반응시킨 후 Microplate Reader (iMARK ${ }^{\mathrm{TM}}$; BIO$\mathrm{RAD}$ )을 이용하여 $420 \mathrm{~nm}$ 에서 흡광도를 측정하였다. 표준곡선은 naringin 농도를 0-300 $\mu \mathrm{g} / \mathrm{mL}$ 이 되도록 하여 작성하고 이로부터 총 플라보노이드 함량을 구하였다.

\section{ABTS 라디칼 소거활성 측정}

2,2'-azinobis-(3-ethyl-benzothiazoline-6-sulphonic acid (ABTS) 와 potassium persulfate를 혼합하여 암소에 두면 ABTS 라디 칼이 생성되는데 추출물의 항산화 물질과 반응하여 양이온이 소거됨 으로써 특유의 청록색이 탈색되며 이의 흡광도를 측정하여 항산화 능 력을 측정할 수 있다. 시험 용액은 증류수에 $7 \mathrm{mM} \mathrm{ABTS와} 2.45 \mathrm{mM}$ potassium persulfate를 첨가하여 상온에서 $16 \mathrm{~h}$ 배양하여 ABTS 양 이온을 생성시킨 후 $734 \mathrm{~nm}$ 에서 흡광도의 값이 0.7 이하가 되도록 희 석하여 제조하였다. 그 다음 ABTS 용액 $100 \mu \mathrm{L}$ 에 시료 용액 $100 \mu \mathrm{L}$ 을 가한 후 $6 \mathrm{~min}$ 후에 흡광도(iMARK ${ }^{\mathrm{TM}}$; $\left.\mathrm{BIO}-\mathrm{RAD}\right)$ 를 측정하였다. 음성대조군( $2.45 \mathrm{mM}$ potassium persulfate buffer)의 흡광도와 비교 
하여 흡광도를 감소시키는 정도를 \%로 나타내었다.

\section{SOD 유사활성 측정}

SOD 유사활성 측정은 Marklund \& Marklund (1974)의 방법에 따 라 측정하였다. 생강 잎, 줄기, 뿌리 추출물 $0.2 \mathrm{~mL}$ 에 $\mathrm{pH}$ 8.5로 보 정한 tris $-\mathrm{HCl}$ buffer $3 \mathrm{~mL}$ 와 $7.2 \mathrm{mM}$ pyrogallol $0.2 \mathrm{~mL}$ 를 첨가하 였다. $25^{\circ} \mathrm{C}$ 에서 $10 \mathrm{~min}$ 반응시킨 후 $1 \mathrm{~N} \mathrm{HCl}$ 로 반응을 정지시킨 다 음 ELISA reader (Molecular Devices)를 이용하여 $420 \mathrm{~nm}$ 에서 흡광 도를 측정하였다. 활성비교를 위하여 항산화 물질로 잘 알려진 BHT, ascorbic acid 와 비교하였다. SOD 유사활성은 추출물의 첨가구와 무 첨가구의 흡광도 감소율로 나타내었다.

\section{6. 생강 잎, 줄기, 뿌리 추출물의 $\mathrm{HaCaT}$ 세포 보호효과 측정 1) 세포배양}

Human keratinocyte (HaCaT) 세포는 한국세포주은행(Korean Cell Line Bank, KCLB, Korea)에서 분양 받았으며, 세포배양을 위해 $10 \% \mathrm{FBS}$ 과 $1 \%$ penicillin-streptomycin을 포함하는 DMEM 배지를 사용하였다. 세포는 $37^{\circ} \mathrm{C}, 5 \% \mathrm{CO}_{2}$ 조건에서 배양하였다.

\section{2) 세포 생존율 측정}

생강 잎, 줄기, 뿌리 추출물의 안전성 시험으로 세포 생존율 측정은 MTT 방법으로 측정하였다. HaCaT 세포 $5 \times 10^{4}$ cells/well를 96 well plate에 분주하여 $24 \mathrm{~h}$ 배양 후 생강 잎, 줄기, 뿌리 추출물을 농도별 (5-400 $\mu \mathrm{g} / \mathrm{mL}$ )로 처리하여 $24 \mathrm{~h}$ 재 배양하였다. 재 배양 후 well 당 $20 \mu \mathrm{L}$ 의 MTT 용액을 첨가하여 $37^{\circ} \mathrm{C}, 5 \% \mathrm{CO}_{2}$ incubator에서 $4 \mathrm{~h}$ 동 안 반응시킨 후, ELISA reader (Molecular Devices)를 이용하여 540 $\mathrm{nm}$ 에서 흡광도의 변화를 측정하여 대조군에 대한 세포 생존율을 백 분율로 표시하였다.

3) $\mathrm{H}_{2} \mathrm{O}_{2}$ 에 의해 유발되는 산화적 스트레스에 대한 HaCaT 세포 보호 효과

$\mathrm{H}_{2} \mathrm{O}_{2}$ 에 의해 유발되는 산화적 스트레스에 대한 $\mathrm{HaCaT}$ 세포 보호 효과는 MTT법을 변형하여 측정하였다. 96 well plate에 $\mathrm{HaCaT}$ 세포 를 $1 \times 10^{5}$ cells/well의 농도로 조절하여 $24 \mathrm{~h}$ 배양 후, 세포 생존율 에 따라 생강 잎, 줄기, 뿌리 추출물을 $4 \mathrm{~h}$ 전처리 후, 최종 농도 500 $\mu \mathrm{M}$ 의 $\mathrm{H}_{2} \mathrm{O}_{2}$ 를 함유한 배양액을 투여하여 $24 \mathrm{~h}$ 동안 반응시키고, 배 양이 끝난 후 배양액을 제거하고 각 well에 생성된 formazan 결정에 $\mathrm{DMSO}$ 를 첨가하여 녹인 다음 ELISA reader (Molecular Devices)를 이용하여 $540 \mathrm{~nm}$ 에서 흡광도를 측정하였다.

\section{7. 생강 부위별 추출물의 인간 모유두 세포 증식효과 측정}

1) 세포배양

본 실험에 사용된 인간 모유두 세포(human follicle dermal papilla cell, HFDPC)는 Promocell 사에서 구매 사용 하였으며, 세포의 배양과

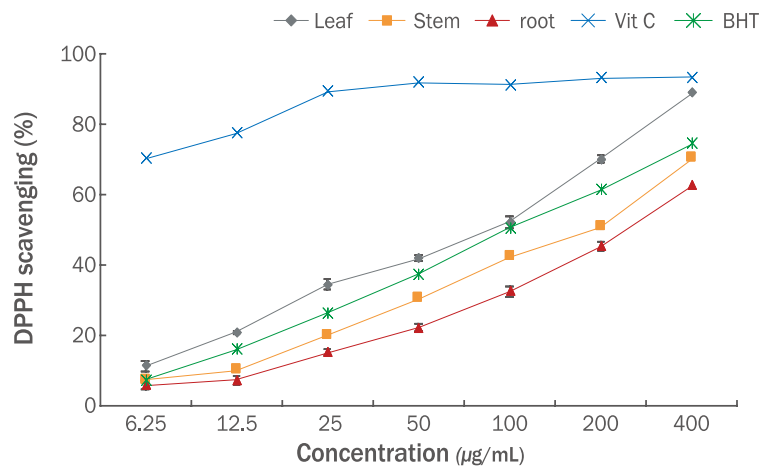

Figure 1. DPPH scavenging activity of leaf, stem, and root extracts of Zingiber officinale.

Activities were determined by measuring the absorbance at 517 $\mathrm{nm}$. Vit C, ascorbic acid, BHT, butylated hydroxy toluene group. The results are mean \pm S.D. of three replications.

실험에는 Promocell의 HFDPC 세포 배양 전용 배지인 Follicle Dermal Papilla Cell Growth Medium (Ready-to-use, Cat. No. C-26501; Heidelber, Germany)을 사용하였으며, 배양과 계대배양 및 실험용 세 포의 준비는 Promocell에서 제공하는 실험법에 준하여 수행하였다.

\section{2) 세포 생존율 측정}

생강 잎, 줄기, 뿌리 추출물의 세포 생존율 측정은 MTT 방법으 로 측정하였다. 모유두 세포 $5 \times 10^{4}$ cells/well를 96 well plate에 분 주하고 생강 잎, 줄기, 뿌리 추출물을 농도별 $(5-400 \mu \mathrm{g} / \mathrm{mL})$ 로 $24 \mathrm{~h}$ 동안 처리하였다. Well 당 $20 \mu \mathrm{L}$ 의 MTT 용액을 첨가하여 $37^{\circ} \mathrm{C}, 5 \%$ $\mathrm{CO}_{2}$ incubator에서 $4 \mathrm{~h}$ 동안 반응시킨 후, ELISA reader (Molecular Devices)를 이용하여 $540 \mathrm{~nm}$ 에서 흡광도의 변화를 측정하여 대조군 에 대한 세포 생존율을 백분율로 표시하였다.

\section{3) 모유두 세포 증식효과 측정}

생강 잎, 줄기, 뿌리 추출물의 모유두 세포 증식효과 측정은 MTT 방법으로 분석하였다. 모유두 세포 $5 \times 10^{4}$ cells/well를 96 well plate 에 분주하고 생강 잎, 줄기, 뿌리 추출물을 농도별 $(5-100 \mu \mathrm{g} / \mathrm{mL})$ 로 $72 \mathrm{~h}$ 동안 처리하였다. Well 당 $20 \mu \mathrm{L}$ 의 MTT 용액을 첨가하여 $37^{\circ} \mathrm{C}, 5 \% \mathrm{CO}_{2}$ incubator에서 $4 \mathrm{~h}$ 동안 반응시킨 후, ELISA reader (Molecular Devices)를 이용하여 $540 \mathrm{~nm}$ 에서 흡광도의 변화를 측정 하여 대조군에 대한 세포 증식효과를 백분율로 표시하였다.

\section{8. 통계처리}

본 연구의 모든 실험 결과는 3 회 이상 반복하여 평균값으로 나타내 었으며, 통계학적 유의성은 Student's $t$-test로 분석하였으며, $p$ value 가 0.05 미만일 경우 통계적으로 유의한 것으로 판정하였다 ${ }^{*} p<0.05$, $\left.{ }^{* *} p<0.01\right)$. 


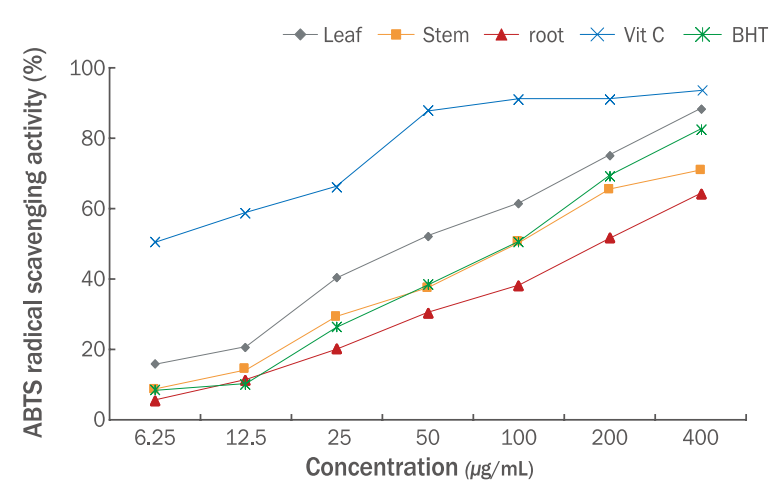

Figure 2. ABTS radical scavenging activity of leaf, stem, and root extracts of Zingiber officinale.

Activities were determined by measuring the absorbance at 734 $\mathrm{nm}$. Vit C, ascorbic acid; BHT, butylated hydroxy toluene group. The results are mean \pm S.D. of three replications.

\section{Results and Discussion}

\section{DPPH 라디칼 소거능}

생강 잎, 줄기, 뿌리 추출물 시료를 $6.25-400 \mu \mathrm{g} / \mathrm{mL}$ 범위에서 처 리하였을 때 시료 농도에 따른 DPPH 라디컬 소거율은 Figure 1과 같 으며 $400 \mu \mathrm{g} / \mathrm{mL}$ 의 농도에서 생강 잎 추출물은 $88.78 \%$, 줄기 추출 물은 $70.12 \%$, 뿌리 추출물은 $65.52 \%$ 의 $\mathrm{DPPH}$ 라디컬 소거능이 확 인 되었다. 양성 대조군으로 사용한 BHT은 Vit C는 $93.25 \%$, BHT은 $74.38 \%$ 의 소거능이 확인 되었다. 활성 라디칼인 $\mathrm{DPPH}$ 는 ascorbic acid, tocopherol, polyhydroxy phenol 화합물 및 방향성 아민 등에 의하여 환원되어 탈색이 되는 성질을 이용하여 식물체 추출물의 항산 화효과를 신속하고 간단하게 측정하는데 널리 사용되고 있으며, 여러 연구에서 $\mathrm{DPPH}$ 라디칼 소거능 및 lipoxygenase활성 억제 효과는 총 폴리페놀 함량과 상호 관련성이 매우 높은 것으로 보고되었다(Kwak \& Lee, 2014). Lee \& Jhoo (2012)의 연구에서 싸리나무 잎, 줄기, 뿌 리 추출물의 $\mathrm{DPPH}$ 소거능 측정 결과 싸리나무 잎이 가장 높은 소거 능이 확인되었다. Lee et al. (2014)의 연구에서도 생강 잎, 줄기, 뿌 리의 항산화 활성을 측정한 결과 생강의 잎, 줄기에서도 높은 황산화 활성을 확인되어 생강은 뿌리 단독보다는 뿌리와 잎, 줄기를 모두 활 용하는 것이 바람직하나 잎의 경우 식용으로 인정되지 있지 않아 이 를 활용하기 위한 허가 추진 및 제도 개선이 필요하다고 하였다. 본 연구에서도 생강 잎 추출물이 항산화 활성이 높게 확인되었다.

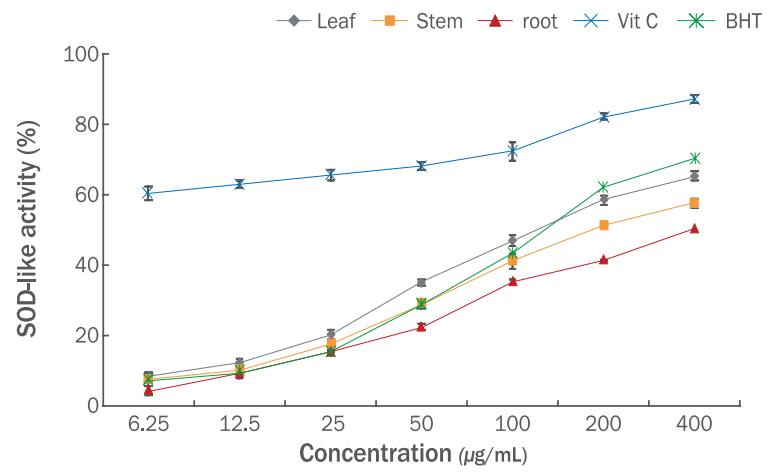

Figure 3. SOD-like activity of leaf, stem, and root extracts of Zingiber officinale.

Activities were determined by measuring the absorbance at 420 $\mathrm{nm}$. Vit C, ascorbic acid; BHT, butylated hydroxy toluene group. The results are mean \pm S.D. of three replications.

\section{2. 총 폴리페놀 및 총 플라보노이드 함량}

천연 폴리페놀성 화합물은 식물계에 널이 분포된 2차 대사산물 의 하나로 다양한 구조와 분자량을 가진다. 이들은 이들은 phenolic hydroxy $(\mathrm{OH})$ 기를 가지기 때문에 단백질 및 기타 거대 분자들과 쉽 게 결합하여, 항산화, 항암 등의 다양한 생리활성을 가지는 것으로 알 려져 있다(Lee \& Lee, 2016). 생강 부위별 추출물 $1 \mathrm{mg} / \mathrm{mL}$ 에 포함 되어 있는 총 폴리페놀의 함량은 tannic acid 함량으로 환산하여 나타 낸 결과 Table 1 와 같다. 생강 잎 추출물은 $170.22 \pm 1.03 \mu \mathrm{g} / \mathrm{mL}$, 줄 기 추출물은 $120.27 \pm 1.21 \mu \mathrm{g} / \mathrm{mL}$, 뿌리 추출물은 $146 \pm 1.01 \mu \mathrm{g} /$ $\mathrm{mL}$ 의 함량이 확인되었다.

Diethylene glycol 비색법에 의한 생강 부위별 추출물 $1 \mathrm{mg} / \mathrm{mL}$ 의 총 플라보노이드 함량은 naringin 함량으로 환산하여 나타낸 결과 Table 1 와 같았다. 생강 잎 추출물은 $98.52 \pm 1.03 \mu \mathrm{g} / \mathrm{mL}$, 줄기 추출 물은 $70.26 \pm 1.21 \mu \mathrm{g} / \mathrm{mL}$, 뿌리 추출물은 $46.12 \pm 1.01 \mu \mathrm{g} / \mathrm{mL}$ 의 함 량이 확인되었다. 이상의 결과 생강 잎 추출물이 총 폴리페놀과 플라 보노이드 함량이 가장 높게 확인되었다. Chon et al. (2012b)은 민들 레 꽃, 잎 및 뿌리 등의 메탄올 추출물의 총 플라보노이드 및 페놀성 화합물의 함량을 분석한 결과 잎이 가장 우수한 것으로 보고하였다. 본 연구 결과에서도 잎 추출물이 가장 우수하였다.

\section{ABTS 라디칼 소거활성}

$\mathrm{ABTS}+$ 는 비교적 안정적인 free radical로써, $\mathrm{DPPH}$ 와 함께 항산

Table 1. Total phenolic and flavonoid contents of leaf, stem, and root extracts of Zingiber officinale

\begin{tabular}{lcc}
\hline Sample & Total phenols $(\mu \mathrm{g} / \mathrm{mL})$ & Total flavonoids $(\mu \mathrm{g} / \mathrm{mL})$ \\
Leaf & $170.22 \pm 1.03$ & $98.52 \pm 1.03$ \\
Stem & $120.27 \pm 1.21$ & $70.26 \pm 1.21$ \\
Roof & $146.14 \pm 1.01$ & $46.12 \pm 1.01$ \\
\hline
\end{tabular}




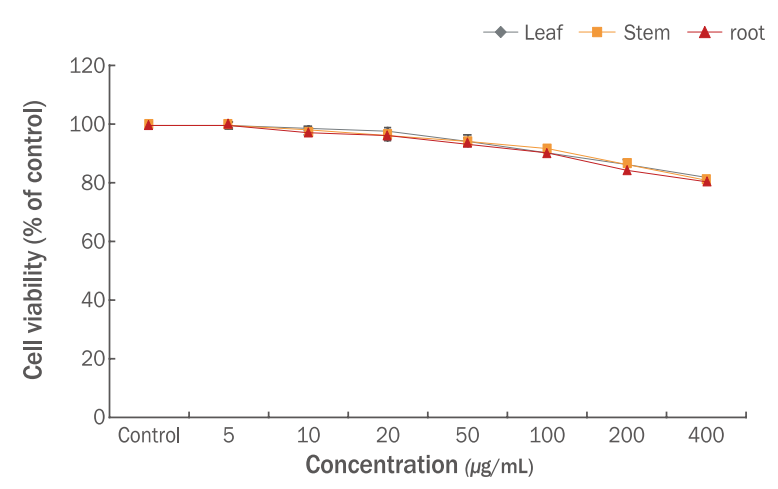

Figure 4. Effect of leaf, stem, and root extracts of Zingiber officinale on cytotoxicity in HaCaT cells.

HaCaT cells were incubated with Zingiber officinale extract at the indicated concentration. After $24 \mathrm{~h}$, cell viability was measured by MTT assay. The results are mean \pm S.D. of three replications.

화 활성 측정에 널리 쓰이는 방법 중 하나이다. 이 실험은 potassium persulfate와 ABTS의 산화에 의해 $\mathrm{ABTS}+$ 가 활성양이온이 된 후 시 료의 항산화력에 의해 $\mathrm{ABTS}^{+}$가 소거되며 청록색으로 탈색되는데 이 때의 흡광도를 측정하여 항산화력을 관찰한다(Kang et al., 2015). 그 결과 Figure 2과 같으며, $400 \mu \mathrm{g} / \mathrm{mL}$ 의 농도에서 생강 잎 추출물은 $88.26 \%$, 줄기 추출물은 $70.73 \%$, 뿌리 추출물은 $64.13 \%$ 의 ABTS 라 디칼 소거능이 확인되었다. Lee \& Jhoo (2012)의 연구에서 싸리나무 잎, 줄기, 뿌리 추출물의 DPPH 소거능 측정 결과 싸리나무 잎이 가장 높은 소거능이 확인되었는데 이는 본 연구결과와 비슷한 결과를 가져 왔다.

\section{4. $\mathrm{SOD}$ 유사활성 측정}

$\mathrm{SOD}$ 는 superoxide radical을 과산화수소와 정상상태의 산소로 환원시켜줌으로써 노화 억제 등의 항산화 역할을 한다(Han et al., 2015). 항산화 효소 중의 하나인 superoxide dismutase (SOD)는 반 응성이 매우 강한 superoxide radical $\left(\mathrm{O}_{2}^{-\bullet}\right)$ 과 반응하여 hydrogen peroxide $\left(\mathrm{H}_{2} \mathrm{O}_{2}\right)$ 생성을 촉매하는 효소로 산소를 소비하는 모든 생 물종에 존재하며 대표적인 활성산소 저해제이다. 가장 독성이 강한 hydroxy radical의 생성을 예방하는 작용을 하여 현재 항염증 소재나 피부노화 방지를 위한 미용소재로 화장품 등의 첨가제로 이용되고 있 다(Kim et al., 2015).

이러한 피부 염증 및 노화 방지와 관련이 있는 $\mathrm{SOD}$ 유사활성을 측 정한 결과, Figure 3 와 같으며, $400 \mu \mathrm{g} / \mathrm{mL}$ 의 농도에서 생강 잎 추출 물은 $65.22 \%$, 잎 추출물은 $57.53 \%$, 줄기 추출물은 $50.21 \%$ 의 SOD 유사활성능이 확인 되었다.

\section{5. 생강 잎, 줄기, 뿌리 추출물의 $\mathrm{HaCaT}$ 세포 보호효과 측정 \\ 1) 세포 생존율}

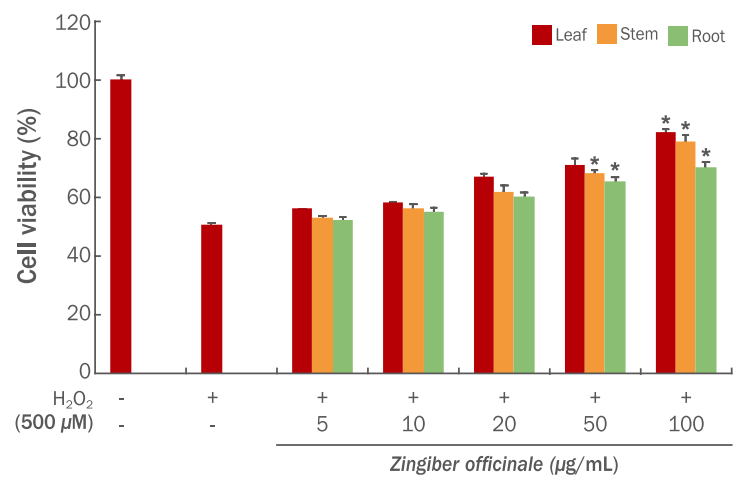

Figure 5. Protective effect of leaf, stem, and root extracts of Zingiber officinale on oxidative stress induced by $\mathrm{H}_{2} \mathrm{O}_{2}$ in human HaCaT cells.

The cells were incubated with Zingiber officinale extracts for $4 \mathrm{~h}$ followed by treatment with $500 \mu \mathrm{M} \mathrm{H}_{2} \mathrm{O}_{2}$ for $24 \mathrm{~h}$ and cell viability was measured by MTT assay. The results are mean \pm S.D. of three replications $\left({ }^{*} p<0.05\right)$.

화장품 소재로 안전성을 확인하기 위해 가장 많이 사용되는 세포 생존율 실험을 통해 평가하였다. 각질세포(keratinocyte)는 표피세포 에 해당하며 자외선을 비롯한 외부 자극에 직접적으로 노출되게 된 다. 이러한 지속적인 자외선화 같은 외부 자극의 노출을 통해 산화적 스트레스(oxidative stress)가 발생하게 되며 이는 피부가 노화되는 가 장 큰 원인으로 알려져 있다(Seo \& Jeong, 2015). 생강 잎, 줄기 뿌리 추출물이 $\mathrm{HaCaT}$ 세포 생존율에 미치는 영향을 확인하기 위하여 농도 별(5-400 $\mu \mathrm{g} / \mathrm{mL}$ )로 처리하고, 24시간 배양한 후에 MTT assay 방법 으로 세포 생존율을 측정하였다. 실험 결과 Figure 4 와 같이 생강 잎, 줄기, 뿌리 추출물은 $5 \mu \mathrm{g} / \mathrm{mL}$ 부터 $100 \mu \mathrm{g} / \mathrm{mL}$ 까지 약 $90 \%$ 이상의 $\mathrm{HaCaT}$ 세포 생존율을 유지하였으며, $200 \mu \mathrm{g} / \mathrm{mL}$ 이상의 농도에서는 $\mathrm{HaCaT}$ 세포에 대해 독성 효과를 나타냈다. 이상의 결과로 보아 적당 한 농도 $(5-100 \mu \mathrm{g} / \mathrm{mL})$ 의 생강 잎, 줄기, 뿌리 추출물은 $\mathrm{HaCaT}$ 세포 에 대해 독성을 나타내지 않았으며, 따라서 다음에 진행된 실험에서 는 $5 \mu \mathrm{g} / \mathrm{mL}$ 부터 $100 \mu \mathrm{g} / \mathrm{mL}$ 까지 생강 잎, 줄기, 뿌리 추출물을 사용 하였다.

\section{2) 과산화수소로 유도된 HaCaT 세포 보호효과}

과산화수소는 세포 내에서 $\mathrm{O}_{2}{ }^{-}$가 $\mathrm{SOD}$ 로 촉매되어 생성되거나 자 외선 조사에 의해서 과잉 생산되면 산화적 손상을 일으키게 된다. 활 성산소인 과산화수소는 세포막을 통과하여 생체내 미량으로 존재하 는 금속 이온과 반응하여 다른 ROS를 생성시켜 세포 손상을 야기 시 킨다(Lee et al., 2018). 과산화수소로 유도된 $\mathrm{HaCaT}$ 세포 손상에 대한 생강 잎, 줄기, 뿌리 추출물의 세포 보호효과를 Figure 5 에 나 타냈다. 실험결과, 과산화수소 $(500 \mu \mathrm{M})$ 를 처리한 실험군은 처리하 지 않은 군(100\%)에 비해 약 $50.70 \%$ 의 세포 생존율을 나타냈다. 생 강 잎, 줄기, 뿌리 추출물 $(5-100 \mu \mathrm{g} / \mathrm{mL})$ 을 처리한 군은 세포 생존율 


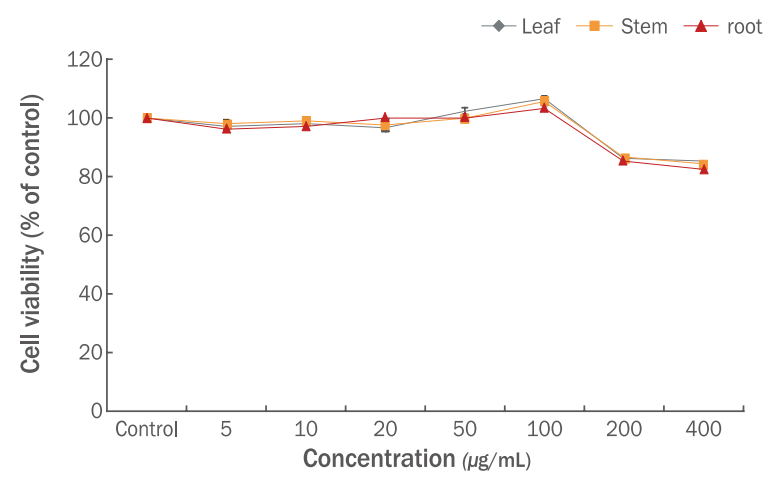

Figure 6. Effect of leaf, stem, and roots extract of Zingiber officinale on cytotoxicity in HFDPC cells.

The cells were incubated with the stem extract of Zingiber officinale at the indicated concentration. After $24 \mathrm{~h}$, cell viability was measured by MTT assay. The results are mean \pm S.D. of three replications.

이 유의적으로 증가하였다. $100 \mu \mathrm{gg} / \mathrm{mL}$ 농도에서 생강 잎 추출물은 $82.18 \%$, 줄기 추출물은 $78.98 \%$, 뿌리 추출물은 $70.27 \%$ 의 생존율을 나타내었다. 이상의 결과 생강 잎 추출물은 $32 \%$ 의 증가율을 나타냄 으로써 과산화수소로 유도된 세포 손상에 대해 보호효과가 높게 확인 되었다.

\section{7. 생강 잎, 줄기, 뿌리 추출물의 인간 모유두 세포 증식효과 측정}

\section{1) 모유두 세포 생존율}

모유두 세포는 모낭내의 여러 종류의 상피세포들과 상호작용을 하 며 모발의 성장 및 주기 조절에 핵심적인 역할을 하고 있으며, 모낭 과 모유두 세포의 상호작용은 모발의 성장에 필수적이다. 특히 모유 두 세포의 성장 증식 및 apoptosis 억제는 모발의 성장기를 유지하 는데 필요함이 보고되어 있다(Kang et al., 2014). 따라서 모유두 세 포의 기능에 영향을 미치는 인자는 탈모를 개선시키기 위한 중요한 표적이 된다(Lim et al., 2011). 생강 잎, 줄기, 뿌리 추출물이 모유 두 세포 생존율에 미치는 영향을 확인하기 위하여 농도 별로 처리하 고, 24시간 배양한 후에 MTT assay 방법으로 측정하였다. 실험 결 과 Figure 6과 같이 생강 잎, 줄기, 뿌리 추출물은 $5 \mu \mathrm{g} / \mathrm{mL}$ 부터 100 $\mu \mathrm{g} / \mathrm{mL}$ 까지 약 $90 \%$ 이상의 모유두 세포 생존율을 유지하였으며, $200 \mu \mathrm{g} / \mathrm{mL}$ 이상의 농도에서는 모유두 세포에 대해 독성 효과를 나 타냈다. 이상의 결과로 보아 적당한 농도 $(5-100 \mu \mathrm{g} / \mathrm{mL})$ 의 생강 잎, 줄기, 뿌리 추출물은 모유두 세포에 대해 독성을 나타내지 않았으며, 따라서 다음에 진행된 실험에서는 $5 \mu \mathrm{g} / \mathrm{mL}$ 부터 $100 \mu \mathrm{g} / \mathrm{mL}$ 까지의 생강 잎, 줄기, 뿌리 추출물을 사용하였다.

\section{2) 모유두 세포 증식효과}

Epithelial cell, mesenchymal cell 등 소기관들로 구성된 모낭은

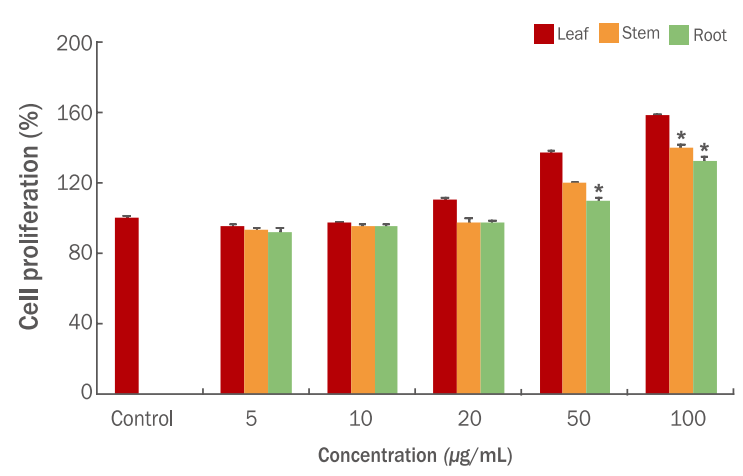

Figure 7. Effect of leaf, stem, and root extracts of Zingiber officinale on cytotoxicity in HFDPC cells.

HFDPC cells were incubated with Zingiber officinale extract at the indicated concentration. After $72 \mathrm{~h}$, cell viability was measured by MTT assay. The results are mean \pm S.D. from three replications $\left({ }^{*} p<0.05\right)$.

모발 성장에 관여한다. 모낭 및 모발의 성장은 복합적이고 주기적 인 방식이며 anagen, catagen 및 telogen의 3단계를 거쳐 일어난다. Mesenchymal cell의 한 종류인 모유두 세포는 상피 세포와 상호작용 하며 모낭에 영양을 공급하여 모발성장 주기를 재생 및 유지하는 역 할을 하므로, 모유두 세포의 증식과 사멸은 모발 성장 조절과 모낭 의 유지 등에 중요한 역할을 하는 것으로 알려져 있다(Back et al., 2017). 생강 잎, 줄기, 뿌리 추출물이 모유두 세포 증식에 미치는 영 향을 확인하기 위해서 추출물을 농도별 $(5,10,20,50,100 \mu \mathrm{g} / \mathrm{mL})$ 처리하고 72시간 배양하여 MTT assay 방법으로 세포 증식효과를 측 정하였다. 생강 잎, 줄기, 뿌리 추출물을 72시간 배양한 결과 Figure 7 와 같으며, $100 \mu \mathrm{g} / \mathrm{mL}$ 농도에서 생강 잎 추출물은 $158.63 \%$, 줄기 추출물은 $140.41 \%$, 뿌리 추출물은 $132.40 \%$ 까지 세포 증식효과를 확인할 수 있었다. 따라서 생강 잎은 $58 \%$ 의 모유두 세포 증식효과가 확인되어 모발의 성장에 도움을 줄 수 있을 것으로 예상된다.

\section{Conclusion}

화장품 시장에서는 심각해지는 환경문제에 대한 선진국들의 움직 임에 의해 합성 원료의 시장성이 축소되고 화장품에 있어 친환경적이 고 식물의 천연성분을 이용하여 생리활성에 도움을 주는 물질을 찾 거나 기존 합성물질에서 나타나는 여러 가지 부작용을 보완할 수 있 는 다양한 천연 원료 개발에 연구가 활발히 진행되고 있다(Kwon, 2017).

따라서 본 연구에서는 생강 잎, 줄기, 뿌리 추출물의 기능성 화장 품 소재로의 가능성을 확인하기 위해 항산화효과, $\mathrm{HaCaT}$ 세포 보호 효과, 모유두 세포 증식효과를 확인하였다. 
첫째, 생강 잎, 줄기, 뿌리추출물의 항산화효과 실험 결과 $\mathrm{DPPH}$ 라디칼 소거능을 측정한 결과 $400 \mu \mathrm{g} / \mathrm{mL}$ 의 농도에서 생강 잎 추출 물은 $88.78 \%$, 줄기 추출물은 $70.12 \%$, 뿌리 추출물은 $65.52 \%$ 으로 확인되었으며, 총 폴리페놀 함량은 생강 잎, 줄기, 뿌리 추출물은 각 각 $170.22,120.27,146 \mu \mathrm{g} / \mathrm{mL}$ 으로 확인되었으며, 총 플라보노이 드는 각각 $98.52,70.26,46.12 \mu \mathrm{g} / \mathrm{mL}$ 의 함량이 확인되었다. ABTS radical 소거능을 측정한 결과 $400 \mu \mathrm{g} / \mathrm{mL}$ 의 농도에서 생강 잎, 줄기, 뿌리 추출물은 각각 88.26, 70.73, 64.13\%으로 확인되었으며, SOD 유사활성 측정결과 생강 잎, 줄기, 뿌리 추출물은 각각65.22, 57.53, $50.21 \%$ 의 소거능이 확인되었다.

둘째, 과산화수소로 유도된 $\mathrm{HaCaT}$ 세포의 산화적 손상에 대한 보 호효과는 $100 \mu \mathrm{g} / \mathrm{mL}$ 농도에서 생강 잎 추출물은 $82.18 \%$, 줄기 추출 물은 $78.98 \%$, 뿌리 추출물은 $70.27 \%$ 의 생존율이 확인되었다.

셋째, 모유두 세포 증식효과는 생강 잎, 줄기, 뿌리 추출물을 72 시 간 배양한 결과 $100 \mu \mathrm{g} / \mathrm{mL}$ 농도에서 생강 잎 추출물은 $158.63 \%$, 줄 기 추출물은 $140.41 \%$, 뿌리 추출물은 $132.40 \%$ 까지 세포 증식효과 를 확인할 수 있었다.

이상의 연구 결과 생강 부위별 추출물 중 잎 추출물이 항산화효과, $\mathrm{HaCaT}$ 세포 보호효과, 모유두 세포 증식효과가 가장 우수하여 기능 성 화장품 소재 개발로 충분한 가능성이 있음을 확인하였다.

\section{Acknowledgements}

본 연구는 2019년도 남부대학교 학술연구비의 지원을 받아 연 구되었음.

\section{Author's contribution}

SML and CDK contributed equally to this work. SML and CDK designed all experimental investigations and developed a process to check the possibilities with cosmetic materials. SML designed and supported the experiment, participated in the experiment, and CDK wrote the manuscript with the help of SML.

\section{Author details}

Sang Moo Lee (Adjunct Professor), Department of Cosmetology Science, Nambu University, 23 advanced Jungang-ro, Gwangsan-gu, Gwangju 62271, Korea; Chun Dug Kim (Professor), Department of Cosmetology Science, Nambu University, 23 advanced Jungang-ro, Gwangsangu, Gwangju 62271, Korea.

\section{References}

Back MH, Seo MC, Kim MA, Yun EY, Hwang JS. The antioxidant activities and hair-growth promotion effects of Tenebrio molitor Larvae extracts (TMEs). Journal of Life Science, 27: 1269-1275, 2017.

Blois MS. Antioxidant determinations by the use of a stable free radical. Nature, 181: 1199-1200, 1958.

Cho YJ. Characteristics of cosmetic with whitening compounds from Phellodendron amurense. Applied Biological Chemistry, 54: 108-113, 2011.

Chon JW, Kweon HY, Jo YY, Park MK, Son YH, Lee HS. A study on the development of functional cosmetics using silkgland powder of silkworm. Journal of the Society of Cosmetic Scientists of Korea, 38: 163-169, 2012a.

Chon SU, Bas CH, Lee SC. Antioxidant and cytotoxic potentials of methanol extracts from Taraxacum officinale F. $\mathrm{H}$. Wigg. at different plant parts. Korean Journal of Plant Resources, 25: 232-239, 2012b.

Folin O, Denis W. A colorimetric method for the determination of phenols (and phenol derivatives) in urine. The Journal of Biological Chemistry, 22: 305-308, 1915.

Han JH, Moon HK, Chung SK, Kang WW. Comparison of physiological activities of radish bud (Raphanus sativus L.) according to extraction solvent and sprouting period. Journal of the Korean Society of Food Science and Nutrition, 44: 549-556, 2015.

Jang HS, Jang AR, Song YS, Kim MK. A study on physiological activities of skin care cosmetic material of Robinia pseudoacacia flower extracts. Journal of The Korean Society of Cosmetology, 21: 903-910, 2015 .

Jang YA, Kim HN, Yang JC, Lee JW, Kim BA, Lee JT. A study on the possibility of extracts from Sparassis crispa for cosmetic ingredients. Journal of the Korean Applied Science and Technology, 32: 731-739, 2015b.

Kwak CS, Lee JH. In vitro antioxidant and anti-inflammatory effects of ethanol extracts from sprout of evening primrose (Oenothera laciniata) and Gooseberry (Actinidia arguta). Journal of the Korean Society of Food Science and Nutrition, 43: 207-215, 2014.

Ku HY, Lee KY. Evaluation of the antioxidant effects of extracted seed oils by pressure method using domestic seeds and nuts. Journal of the Korea AcademiaIndustrial cooperation Society, 19: 655-661, 2018. 
Kang MY, Lee SH, Lee SW, Cha SW, Song JL, Lee SC. Effect of Achyranthis radix and Drynariae rhizoma extracts on antioxidant activity and antioxidant enzymes. Korean Journal Plant Resources, 28: 600-607, 2015.

Kang J, Kim MK, Yoo ES, Yoo ID, Kang HK. Effect of clitocybin A on the proliferation of dermal papilla cells. Korean Journal of Pharmacognosy, 45: 288-293, 2014.

Kim JM, Bang IS. Gene expression profiles and antioxidant effects of Houttuynia cordata Thunb extract in human keratinocyte HaCaT cells. Journal of Life Science, 28: 1406-1415, 2018.

Kim M, Park S. Effects of Corchorus olitorius L. (Molokhia) extracts as functional cosmetic materials. Asian Journal of Beauty and Cosmetology, 15: 23-31, 2017.

Kim TY, Jeon TW, Yeo SH, Kim SB, Kim JS, Kwak JS. Antimicrobial, antioxidant and SOD-like activity effect of Jubak extracts. The Korean Journal of Food and Nutrition, 23: 299-305, 2015.

Kim SH, Jang HJ. Study on the bioactive characteristics of Morinda citrifolia as a cosmetic raw material. Journal of the Society of Cosmetic Scientists of Korea, 42: 189193, 2016.

Kwon HJ. Evaluation of the convergence efficacy of cosmetic products containing Pleurotus eringii extracts. Journal of Digital Convergence, 15: 545-550, 2017.

Lee HR, Lee JH, Park CS, Ra KR, Ha JS, Cha MH, Kim SN, Choi YM, Hwang JB, Nam JS. Physicochemical properties and antioxidant capacities of different parts of ginger (Zingiber officinale Roscoe). Journal of the Korean Society of Food Science and Nutrition, 43: 1369-1379, 2014.

Lee SH, Lee SO. Polyphenol contents and antioxidant activities of lentil extracts from different cultivars. Journal of the Korean Society of Food Science and Nutrition, 45: 973-979, 2016.

Lee JH, Jhoo JW. Antioxidant activity of different parts of Lespedeza bicolor and isolation of antioxidant compound. Korean Journal of Food Science and Technology, 44: 763-771, 2012.

Lee SL, Ryu MJ. Antioxidant effects of Cinnamomum cassia bark extract and its effectiveness as a cosmetics ingredient. Asian Journal of Beauty and Cosmetology, 17: 69-80, 2019.

Lee AR, Roh SS, Kim HK. Anti-microbial activity and antiinflammatory effects of fucoidan extracts. Asian Journal of Beauty and Cosmetology, 16: 191-200, 2018.

Lee EJ, Yang SA, Choi HD, Im HG, Whang K, Lee IS. Comparison of gingerols in various fractions and the antioxidant effects of supercritical fluid extracts from ginger. Korean Journal of Food Science and Technology, 43: 469-474, 2011.

Lee YS, Yun ME, Lee YJ, Park YM, Lee SL, Park SN. Antioxidant activities and cytoprotective effects of Lonicera japonica Thunb. extract and fraction against oxidative stress. Microbiology and Biotechnology letters, 46: 18-28, 2018.

Lim NY, Kim DS, Woo WH, Mun YJ, Ko KS. Effect of Fructus Ligustri Lucidi of $\mathrm{H}_{2} \mathrm{O}$ extract on cell proliferation and cell signal pathway in human hair dermal papilla cells. Journal of the Korean Society of Cosmetology, 17: 774779, 2011.

Marklund S, Marklund G. Involvenment of the superoxide anion radical in the autoxidation of pyrogallol and a convenient assay for superoxide dismutase. European Journal of Biochemistry, 47: 469-474, 1974.

Park EK, Park SH, Yoon SA, Kim YS, Lee WR, Kim WJ. Study on photo-aging inhibition effect of microalgae-derived oil for cosmetic material development. Journal of Marine Bioscience and Biotechnology, 10: 83-90, 2018.

Seo SH, Jeong GS. The cytoprotective action of Portulaca oleracea $70 \% \mathrm{EtOH}$ extracts via the heme oxygenase-1 on hydrogen peroxide-induced oxidative stress in human keratinocyte HaCaT cells. Journal of Life Science, 46: 116-122, 2015.

Shim JH. Anti-inflammatory effect of Galium aparine extract in RAW 264.7 cells. Asian Journal of Beauty and Cosmetology, 16: 233-242, 2018.

Yoo ID, Kim JP, Kim WG, Yun BS, Ryoo IJ. Development of new natural antioxidants for cosmeceuticals. Journal of the Society of Cosmetic Scientists of Korea, 31: 349-357, 2005. 


\section{국문초록}

\section{생강 잎, 줄기, 뿌리 추출물의 화장품 소재로서 항산화효과}

이상무, 김춘득

남부대학교 향장미용학과, 광주, 한국

목적: 최본 연구에서는 생강 잎, 줄기, 뿌리 추출물을 응용하여 화장품 소재로서의 가능성을 평가하고자 한다. 방법: 생강 잎, 줄기, 뿌리 추출물의 화장품 소재로의 가능성을 확인하기 위해 항산화효과를 확인하기 위해 DPPH 라디컬 소거능, 총 폴리페놀 및 플라 보노이드 함량, $\mathrm{ABTS}$ 라디칼 소거능, $\mathrm{SOD}$ 유사활성을 측정하였다. 그리고 $\mathrm{H}_{2} \mathrm{O}_{2}$ 에 의해 유발되는 산화적 스트레스에 대한 $\mathrm{HaCaT}$ 세포 보호효과를 확인하였으며, 마지막으로 모유두 세포 증식효과를 확인하였다. 결과: 첫째, 항산화 효과 실험 결과, DPPH 라디 칼 소거능을 측정한 결과 $400 \mu \mathrm{g} / \mathrm{mL}$ 의 농도에서 생강 잎 추출물은 $88.78 \%$, 줄기 추출물은 $70.12 \%$, 뿌리 추출물은 $65.52 \%$ 으로 확 인되었으며, 총 폴리페놀 함량은 생강 잎, 줄기, 뿌리 추출물은 각각 $170.22,120.27,146 \mu \mathrm{g} / \mathrm{mL}$ 으로 확인되었으며, 총 플라보노 이드는 각각 $98.52,70.26,46.12 \mu \mathrm{g} / \mathrm{mL}$ 의 함량이 확인되었다. ABTS radical 소거능을 측정한 결과 $400 \mu \mathrm{g} / \mathrm{mL}$ 의 농도에서 생강 잎, 줄기, 뿌리 추출물은 각각 88.26, 70.73, 64.13\%으로 확인되었으며, SOD 유사활성 측정결과 생강 잎, 줄기, 뿌리 추출물은 각 각65.22, $57.53,50.21 \%$ 의 소거능이 확인되었다. 둘째, 과산화수소로 유도된 HaCaT 세포의 산화적 손상에 대한 보호효과는 100 $\mu \mathrm{g} / \mathrm{mL}$ 농도에서 생강 잎 추출물은 $82.18 \%$, 줄기 추출물은 $78.98 \%$, 뿌리 추출물은 $70.27 \%$ 의 생존율이 확인되었다. 실험 결과 생 강 잎 추출물이 $32 \%$ 의 증가율을 나타냄으로써 과산화수소로 유도된 세포 손상에 대해 보호효과가 높게 확인되었다. 셋째, 모유두 세포 증식효과는 생강 잎, 줄기, 뿌리 추출물을 72 시간 배양한 결과 $100 \mu \mathrm{g} / \mathrm{mL}$ 농도에서 생강 잎 추출물은 $158.63 \%$, 줄기 추출물 은 $140.41 \%$, 뿌리 추출물은 $132.40 \%$ 까지 세포 증식효과를 확인할 수 있었다. 결론: 이상의 연구 결과 생강 부위별 추출물 중 잎 추 출물이 항산화효과, $\mathrm{HaCaT}$ 세포 보호효과, 모유두 세포 증식효과가 가장 우수하여 화장품 소재 개발로 충분한 가능성이 있음을 확 인하였다.

핵심어: 생강, 항산화 효과, 과산화수소, 모유두세포, 화장품

본 연구는 2019년도 남부대학교 학술연구비의 지원을 받아 연구되었음.

\section{참고문헌}

강미영, 이수현, 이상원, 차선우, 송재림, 이상철. 우슬과 골쇄보의 추출물이 항산화 활성 및 항산화 효소 대사에 미치는 효 과. 한국자원식물학회지, 28: 600-607, 2015.

강정일, 김민경, 유은숙, 유익동, 강희경. Clitocybin A의 모유두 세포증식 효능. 생약학회지, 45: 288-293, 2014. 구희연, 이기영. 국내 종실류를 이용한 압착 오일의 화장품 소재로서 항산화 활성 평가. 한국산학기술학회지, 19: $655-$ $661,2018$.

권혜진. Pleurotus eringii 추출물을 함유한 화장품의 복합효능 평가. 한국디지털정책학회지, 15: 545-550, 2017

곽충실, 이지연. 달맞이순과 다래순 에탄올 추출물의 in vitro 항산화효과 및 항염증효과. 한국식품영양과학회지, 43 :

207-215, 2014.

김미정, 박세연. 기능성 화장품 소재로서 몰로키아 추출물의 가능성. 아시안뷰티화장품학술지, $15: 23-31,2017$.

김정민, 방인석. 인간피부각질세포 $\mathrm{HaCaT}$ 에서 어성초 추출물의 유전체 발현 분석 항산화 효과. 생명과학회지, 28 : 1406-1415, 2018.

김태영, 전태욱, 여수환, 김상범, 김진숙, 곽준수. 주박 추출물의 항균활성, 항산화 및 $\mathrm{SOD}$ 유사활성 효과. 한국식품영양 학회지, 23: 299-305, 2010. 
박은영, 박상희, 윤상아, 김유선, 이우람, 김우중. 화장품 소재 개발을 위한 미세조류 유래 오일의 광노화 억제 효과 연구. 한국해양바이오학회지, 10: 83-90, 2018.

백민희, 서민철, 김미애, 윤은영, 황재삼. 갈색거저리 유충 추출물의 항산화 활성 및 모발 성장 촉진 효과. 한국생명과학회 지, 27: 1269-1275, 2017

심중현. 갈퀴덩굴 추출물에 의한 RAW 264.7 세포에서의 항염 효과. 아시안뷰티화장품학술지, 16: 233-242, 2018. 서승희, 정길생. 마치현 $70 \%$ 에탄올 추출물의 Heme Oxygenase-1발현을 통한 산화적 스트레스에 대한 사람각질형성세 포 보호 효과. 생약학회지, 46: 116-122, 2015.

이소희, 이승욱. 품종별 렌틸 추출물의 폴리페놀화합물 함량 및 항산화 활성. 한국식품영양과학회지. 45: 973-979, 2016.

이아름, 노성수, 김현경. 후코이단 추출물의 항균 및 항산화 효과. 아시안뷰티화장품학술지, 16: 191-200, 2018. 이영숙, 유민정. 계피 추출물의 항산화효과 및 화장품소재의 응용. 아시안뷰티화장품학술지, 17: 69-80, 2019. 이예슬, 윤믿음, 이윤주, 박영민, 이상래, 박수남. 인동덩굴 추출물과 분획물의 항산화 활성 및 산화적 스트레스에 대한 세 포 보호효과. 한국미생물생명공학회지, 46: 18-28, 2018.

이은주, 양선아, 최희돈, 임효권, 황 기, 이인선. 생강 분획의 gingerols 분석 및 초임계 추출물의 항산화 효과. 한국식품과 학회지, 43: 469-474, 2011.

이재학, 주진우. 싸리나무(Lespedeza bicolor) 부위별 추출물의 항산화 활성 및 항산화물질 분리. 한국식품과학회지, 44 : 763-771, 2012.

이혜련, 이종헌, 박철성, 라경란, 하진숙, 차미현, 김세나, 최용민, 황진봉, 남진식. 생강(Zingiber officinale Roscoe) 부 위별 이화학적 특성 및 항산화 활성. 한국식품영양과학회지, 43: 1369-1379, 2014

임난영, 김대성, 우원홍, 문연자, 고경숙. 여정실 물 분획물이 모유두 세포의 증식과 세포내 신호전달에 미치는 영향. 한국 미용학회지, 17: 774-779, 2011.

유익동, 김종평, 김원곤, 윤봉식, 유인자. 천연물 유래 항산화 기능성 화장품 신소재 개발. 대한화장품학회지, $31: 349-$ 357, 2005.

장영아. 양재찬, 김보애. 꽃송이버섯 추출물의 화장품소재로서의 가능성 평가. 한국유화학회지, 32: 731-739, 2015b. 장한솔, 장아람, 송연숙, 김명곤, 이근광. 아카시아 꽃 추출물의 피부미용 화장품 소재 생리활성 연구. 한국미용학회지, 21: 903-910, 2015a.

전정우, 권해용, 조유영, 박명기, 손용호, 이희삼. 누에생실샘 미세분말을 이용한 기능성 화장품 소재 개발에 대한 연구. 대한화장품학회지, 38: 163-169, 2012a.

조영제. Hellodendron amurense의 미백물질을 이용한 화장품 특성. 한국응용생명화학회지, 54: 108-113, 2011. 천상욱, 배창휴, 이성훈. 서양민들레 부위별 추출물의 항산화 및 세포독성 연구. 한국자원식물학회지, 25: 232-239, $2012 b$.

한진희, 문혜경, 정신교, 강우원. 추출용매 및 발아시기에 따른 무순 추출물의 생리활성 비교. 한국식품영양과학회지, $44:$ 549-556, 2015. 


\section{中文摘要}

\section{生姜叶，茎和根提取物作为化妆品原料的抗氧化作用}

李相茂，金春得

南部大学香匠美容学科, 光州, 韩国

目的：在这项研究中，使用了生姜叶，茎和根提取物来评估其作为化妆品原料的潜力。方法：为评估生姜叶， 茎和根提取物作为化妆品原料的潜力, 测定DPPH清除自由基的活性, 总多酚和类黄酮的含量, ABTS清除自 由基的活性以及类 SOD的生理活性, 以确认其抗氧化作用。此外, 还评估了 $\mathrm{HCaT}$ 细胞中 $\mathrm{H}_{2} \mathrm{O}_{2}$ 引起的对氧化 应激的保护作用以及真皮乳头细胞中的增殖作用。结果: 抗氧化测定结果显示, 在 $400 \mu \mathrm{g} / \mathrm{mL}$ 的浓度下, 生姜 DPPH清除自由基的活性分别为 $88.78 \%$ （叶），70.12\%（茎），65.52\%（根）。总多酚含量分别为 170.22 $\mu \mathrm{g} / \mathrm{mL}$ (叶) ， $120.27 \mu \mathrm{g} / \mathrm{mL}$ (茎) 和 $146 \mu \mathrm{g} / \mathrm{mL}$ （根）；总黄酮含量为 $98.52 \mu \mathrm{g} / \mathrm{mL}$ (叶）， $70.26 \mu \mathrm{g} /$ $\mathrm{mL}$ (茎)，和 $46.12 \mu \mathrm{g} / \mathrm{mL}$ （根）。在 $400 \mu \mathrm{g} / \mathrm{mL}$ 的浓度下，ABTS自由基清除活性分别为 $88.26 \%$ (叶）, $70.73 \%$ （茎）和 $64.13 \%$ （根）。此外，类SOD的生理活性为 $65.22 \%$ (叶），57.53\%（茎）和 $50.21 \%$ （根）。在 $100 \mu \mathrm{g} / \mathrm{mL}$ 的浓度下, $\mathrm{HaCaT}$ 细胞中 $\mathrm{H}_{2} \mathrm{O}_{2}$ 引起的对氧化应激的保护作用分别为 $82.18 \%$ (叶）， $78.98 \%$ (茎) 和 $70.27 \%$ （根）。结果证实, 生姜提取物对 $\mathrm{H}_{2} \mathrm{O}_{2}$ 引起的细胞损伤的保护作用增加了 $32 \%$ 。此 外, 当以 $100 \mu \mathrm{g} / \mathrm{mL}$ 的浓度培养细胞 $72 \mathrm{~h}$ 时，在真皮乳头细胞中的增殖作用分别为 $158.63 \%$ (叶），140.41\%

（茎）和 $132.40 \%$ （根）。结论：因此，生姜叶提取物在各部位的提取物中具有最佳的抗氧化作用, HaCaT细胞 保护作用和真皮乳头细胞增殖作用，因此作为化妆品材料具有充分的潜力。

关键词: 生姜，抗氧化作用，过氧化氢，真皮乳头细胞，化妆品 
